\title{
Pengembangan Variasi Latihan Menyerang Menggunakan Pola 2-2 Dalam Olahraga Futsal Tahun 2020
}

\author{
Development of Attacking Exercise Variations Using 2-2 Patterns in Futsal Sports in 2020 \\ Yan Indra Siregar ${ }^{1}$, Ibrahim Akbar ${ }^{2}$ \\ ${ }^{1}$ Fakultas Ilmu Keolahragaan, ${ }^{2}$ Fakultas Teknik, Universitas Negeri Medan \\ Email: dalimuntheibrahim11@gmail.com
}

\begin{abstract}
ABSTRAK
Penelitian ini bertujuan untuk mengembangkan variasi latihan menyerang menggunakan pola 2-2 dalam olahraga futsal. Populasi dalam penelitian ini adalah 40 orang atlet dari $3 \mathrm{club}$ futsal di kota Medan yaitu Tibor Futsal, GOR Dispora dan Kaban Futsal. Bentuk variasi yang telah dibuat terlebih dahulu divalidasi 2 orang ahli yaitu 1 orang pelatih futsal dan 1 orang akademisi olahraga yang berasal dari universitas yang mempunyai latar belakang pendidikan olahraga. Uji kelompok kecil melibatkan 10 orang atlet dan hasilnya telah divalidasi oleh ahli. Validasi yang dilakukan oleh subjek penelitian yang dikategorikan valid/digunakan berjumlah 21 variasi. Hasil uji kelompok besar melibatkan 30 orang atlet dari Tibor Futsal, GOR Dispora dan Kaban Futsal dan hasilnya telah divalidasi oleh ahli dengan jumlah variasi latihan yang dikategorikan/digunakan berjumlah 21 variasi. Validasi yang dilakukan oleh subjek penelitian yang dikategorikan valid/digunakan berjumlah 21 variasi.
\end{abstract}

Kata Kunci: Pengembangan Variasi Latihan, Olahraga Futsal, Pola 2-2.

\begin{abstract}
This study aims to develop a variety of attack training using the 2-2 pattern in futsal. The population in this study were 40 athletes from 3 futsal clubs in the city of Medan, namely Tibor Futsal, GOR Dispora and Kaban Futsal. The form of variation that has been made is validated by 2 experts, namely 1 futsal coach and 1 sports academic from universities who have a sports education background. The small group test involved 10 athletes and the results have been validated by experts. Validation carried out by research subjects categorized as valid/ used totaled 21 variations. The results of the large group test involved 30 athletes from Tibor Futsal, GOR Dispora and Kaban Futsal and the results have been validated by experts with a total of 21 variations of the categorized/ used exercises. Validation carried out by research subjects categorized as valid/ used totaled 21 variations.
\end{abstract}

Keyword: Exercise Variation Development, Futsal Sport, Pattern 2-2.

\section{PENDAHULUAN}

Olahraga adalah suatu bentuk

aktivitas fisik yang telah di rencanakan dan terstruktur yang melibatkan gerakan tubuh secara berulang-ulang dan bertujuan untuk meningkatkan kesehatan jasmani, rohani dan 
meningkatkan daya saing antara individu. Dalam olahraga juga mengajarkan tentang pentingnya suatu kerja sama (Mesnan, dkk, 2020), (Dedy Putranto, Andriadi, 2019).

Olahraga tidak hanya menyehatkan jiwa tetapi dalam olahraga juga mengajarkan kita supaya berlaku sportif, disiplin, sabar, teliti, kerja keras dan konsentrasi (Luh Mastia Andriani, dkk, 2019), (Karo-karo, dkk, 2020)

Futsal merupakan suatu bentuk permainan beregu sama seperti sepakbola hanya saja futsal di mainkan dengan lima lawan lima (Lauh, W. D., \& Fallo, I. S. (2020), sedangkan sepakbola di mainkan sebelas lawan sebelas (Rinaldi Aditya, Filli Azandi, \& M, B. A, 2020). Dari bentuk lapangannya saja sudah berbeda futsal dengan sepakbola. Saat ini futsal sangatlah popular dan digemari banyak kaum laki-laki dan saat ini pun kaum perempuan sudah banyak yang senang dengan olahraga futsal (Farda Kurniawan, dkk, 2020).

Olahraga futsal adalah permainan bola yang dimainkan oleh dua tim, yang mana setiap tim beranggotakan lima orang, tujuan dari olahraga futsal ini iyalah memasukan bola ke gawang lawan dengan menggunakan tubuh selain tangan. Futsal sangatlah cepat perkembangannya di setiap Negara, itu di karenakan olahraga futsal sangatlah menarik untuk dimainkan, karena dalam olahraga futsal berguna untuk melatih kesabaran dan kerja sama tim yang baik dan menunjukan permainan dan skill dalam mengolah bola saat bermain futsal.

Pertama peneliti melakukan observasi di beberapa klub futsal yang ada di kota Medan. Klub futsal yang peneliti observasi yang pertama di klub futsal saudara Medan FC yang dilakukan pada hari rabu, 9 Mei 2018. Klub futsal soudara Medan FC ini baru saja dibentuk oleh coach Safrizal dan sudah cukup terkenal di Kota Medan, karena banyaknya event yang mereka ikuti.

Observasi kedua yang peneliti lakukan di klub futsal PTKS FC, pada hari sabtu, 12 Mei 2018. Klub futsal PTKS FC ini sebenarnya sudah lama berdiri namun sempat bubar karena banyak atlet yang pindah dari klub, namun sekarang klub futsal PTKS FC berdiri lagi dengan coach Heri. Walaupun terbilang baru di tangani oleh coach Heri tetapi prestasi klub futsal PTKS FC cukup baik.

Observasi ketiga yang peneliti lakukan di klub futsal sampali FC, pada hari Senin, 16 Mei 2018. Klub futsal sampali FC ini sudah lama berdiri dan prestasi yang mereka hasilkan sudah cukup banyak, saat 
Pengembangan Variasi Latihan Menyerang Menggunakan Pola 2-2 Dalam Olahraga Futsal Tahun 2020

ini mereka sedang persiapan untuk event liga nusantara.

Peneliti melakukan ovservasi selama satu bulan lebih dengan melihat 4 (empat) kali latihan dan 3 kali laga uji coba atau pertandingan. Dari hasil observasi yang peneliti lakukan peneliti menemukan suatu masalah, yang mana ketika latihan mereka hanya melatih fisik, teknik dan langsung game.

Dari hasil tersebut, peneliti mengangkat suatu masalah yang mana peneliti mengangkat tentang taktik atau strategi dalam bermain, dan peneliti sudah melakukan wawancara dengan pelatihpelatih pada klub yang peneliti observasi dan menanyakan apakah saya boleh melakukan pengembangan variasi atau strategi dalam bermain futsal dan para pelatih memperbolehkan saya melakukan pengembangan variasi dan strategi dalam bermain futsal di klub mereka.

Selain itu, peneliti juga menyebar angket untuk menanyakan apakah para atlet membutuhkan pengembangan variasi atau strategi dalam permainan futsal. Setelah angket disebar ke atlet, peneliti melihat jawaban dari atlet-atlet futsal. Para atlet menjawab sangat membutuhkan pengembangan variasi atau strategi dalam bermain futsal dan peneliti juga mewawancarai beberapa atlet dan jawaban mereka sama karena ketika latihan mereka jarang sekali melakukan variasi-variasi menyerang maupun bertahan. Tujuan dari penelitian ini adalah untuk meningkatkan wawasan tentang variasi-variasi latihan dalam futsal.

\section{METODE PENELITIAN}

Penelitian jenis ini berbeda dengan penelitian pendidikan lainnya karena tujuannya adalah mengembangkan produk berdasarkan uji coba untuk kemudian direvisi sampai menghasilkan produk yang layak pakai (Research and Development). Metode penelitian pengembangan adalah metode penelitian yang digunakan untuk menghasilkan produk tertentu, dan menguji keefektifan produk tersebut Syahputra, W. D., 2020).

Borg and Gall (dalam Sugiyono, 2011: 4) menyatakan bahwa penelitian pengembangan adalah suatu proses yang digunakan untuk mengembangkan dan memvalidasi produk-produk yang digunakan dalam latihan. Pada uji coba tahap satu penelitian melibatkan sebanyak 10 prang dan pada tahap uji coba dua peneliti melibatkan sebanyak 30 orang. Pada 
penelitian dan pengembangan ini bertujuan untuk mengembangkan variasi latihan menyerang.

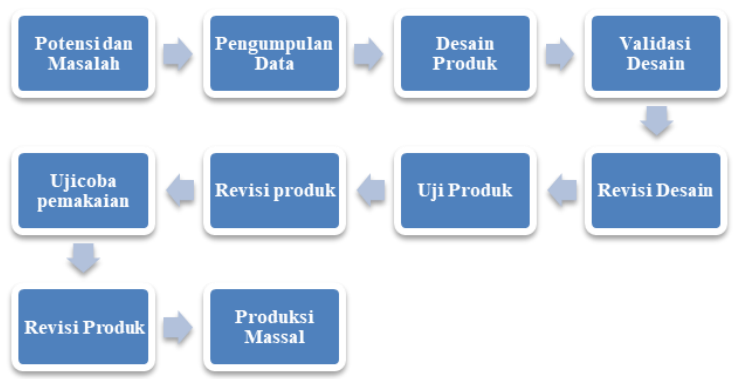

Gambar 1. Langkah Pengembangan

\section{HASIL DAN PEMBAHASAN}

Pengembangan variasi latihan penyerangan menggunakan pola 2-2 dalam olahraga futsal ini telah tertulis dalam naskah yang menyajikan bentuk variasi latihan penyerangan dengan menggunakan pola 2-2 dalam olahraga futsal. Tujuan pengembangan variasi latihan penyerangan dengan menggunakan pola 2-2 dalam olahraga futsal dalam studi pendahuluan yaitu untuk mengetahui seberapa penting pengembangan variasi latihan penyerangan dengan menggunakan pola 2-2 dalam olahraga futsal.

Hasil wawancara yang diperoleh dari pelatih futsal bahwa mereka sangat membutuhkan pengembangan variasi latihan penyerangan pola 2-2 dalam olahraga futsal karena sampai saat ini untuk menambah kemampuan menyerang pola 2-2 dalam olahraga futsal masih menggunakan variasi yang masih lama atau yang sudah ada. Berdasarkan analisis kebutuhan maka peneliti ingin mengembangkan variasi latihan penyerangan pola 2-2 dalam olahraga futsal untuk mempermudah pelatihpelatih menambah kemampuan menyerang pada atletnya.

Pengembangan variasi latihan penyerangan dengan menggunakan pola 2-2 yang telah dievaluasi ahli, pernyataan dan saran yang diperoleh akan digunakan sebagai landasan dalam melakukan tahapan uji coba tahap I. Berikut merupakan hasil validasi oleh para ahli pelatih futsal, ahli olahraga, dan ahli bahasa:

\section{Tabel 1. Hasil Validasi Ahli}

\begin{tabular}{|c|c|c|}
\hline Nama Ahli & $\begin{array}{c}\text { Persentase } \\
\text { Jawaban } \\
\text { Angket }\end{array}$ & Kesimpulan \\
\hline $\begin{array}{l}\text { Heri Wahyudi, } \\
\text { S.Pd } \\
\text { (Pelatih Futsal) }\end{array}$ & $85 \%$ & $\begin{array}{l}\text { Variasi } \\
\text { Sangat Baik } \\
\text { dan Dapat } \\
\text { Digunakan }\end{array}$ \\
\hline $\begin{array}{l}\text { Irwansyah } \\
\text { siregar, S.Pd, } \\
\text { M.Pd. } \\
\text { (Ahli Olahraga) }\end{array}$ & $95 \%$ & $\begin{array}{l}\text { Variasi } \\
\text { Sangat Baik } \\
\text { dan Dapat } \\
\text { Digunakan }\end{array}$ \\
\hline $\begin{array}{l}\text { Nurul Husna, } \\
\text { S.Pd, } \\
\text { (Ahli Bahasa) }\end{array}$ & $85 \%$ & $\begin{array}{l}\text { Variasi } \\
\text { Sangat Baik } \\
\text { dan Dapat } \\
\text { Digunakan }\end{array}$ \\
\hline $\begin{array}{r}\text { Uji coba } \\
\text { (kelompok kecil) }\end{array}$ & $\begin{array}{l}\text { produk I } \\
\text { dilakukan }\end{array}$ & $\begin{array}{l}\text { ang pertama } \\
\text { di klub futsal }\end{array}$ \\
\hline
\end{tabular}


terdiri dari 10 sampel penelitian. Berikut hasil dari uji coba produk kelompok kecil:

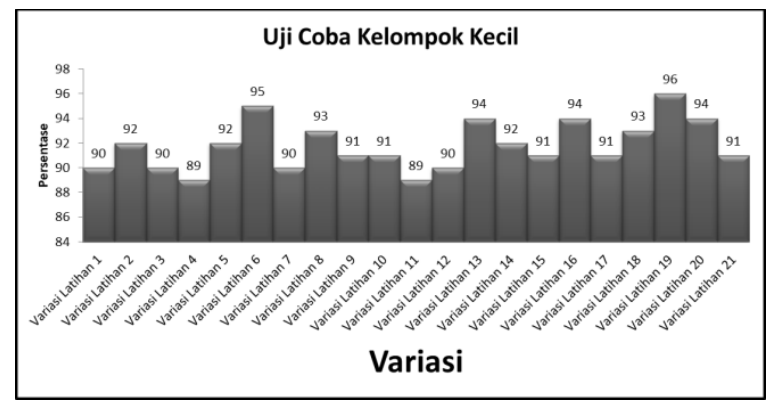

Gambar 2. Hasil uji coba kelompok kecil

Pada tahapan ini uji coba dilakukan terhadap tiga klub sepakbola yaitu klub futsal PTKS, The Class dan Sir KQFC dimana keseluruhan sampel uji coba adalah sebanyak 30 sampel penelitian. Berikut hasil uji coba kelompok besar:

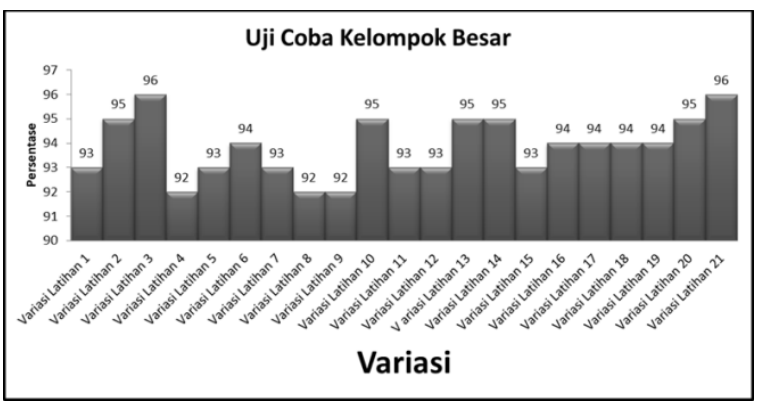

Gambar 3. Hasil uji coba kelompok besar

Pengembangan produk variasi latihan ini bertujuan untuk mengembangkan variasi-variasi latihan menyerang menggunakan pola 2-2 yang baru yang belum dikembangkan dengan baik sampai saat ini. Produk yang dikembangkan ini didasari dengan adanya kebutuhan para pelatih club-club futsal dan pemain yang sampai saat ini belum pernah mendapatkan variasi latihan penyerangan dengan menggunakan pola 2-2 yang baru seperti ini dalam olahraga futsal (Paranoan, A., \& Prastya, A. N., 2019). Berdasarkan pembahasan pengembangan produk variasi latihan penyerangan dengan menggunakan pola 2-2 dalam olahraga futsal yang dilakukan memiliki keunggulan a) Pelatih lebih mudah untuk menambah variasivariasi menyerang menggunakan pola 2-2 kepada atlet nya, b) Atlet lebih termotivasi untuk meningkatkan kemampuan penyerangan dengan menggunakan pola 2-2 untuk menambah pengetahuan mereka.

\section{KESIMPULAN}

Berdasarkan hasil penelitian dan pengembangan ini dapat disimpulkan bahwa: Pengembangan variasi latihan penyerangan dengan menggunakan pola 2-2 dalam olahraga futsal sangat dibutuhkan untuk menambah dan mengembangkan variasi-variasi latihan yang lebih baru untuk kemampuan menyerang club-club futsal. Pengembangan variasi latihan penyerangan dengan menggunakan pola 2-2 dalam olahraga futsal yang diciptakan dapat mempermudah pelatih futsal untuk menambah kemampuan penyerangan 
dengan menggunakan pola 2-2 kepada club dan pemainnya. Pengembangan variasi latihan penyerangan dengan menggunakan pola 2-2 dalam olahraga futsal sangat dibutuhkan sebagai acuan untuk lebih berfikir mengembangkan variasi-variasi latihan yang lebih baru dan bervariatif untuk seorang pelatih.

\section{DAFTAR PUSTAKA}

Dahlan, F., Hidayat, R., \& Syahruddin, S. (2020). Pengaruh komponen fisik dan motivasi latihan terhadap keterampilan bermain sepakbola. Jurnal

Keolahragaan, 8(2), 126-139.

Dedy Putranto, Andriadi Andriadi. (2019). Pengembangan Model Latihan Passing ADE Sepakbola. SPORTIVE: Journal Of Physical Education, Sport and Recreation. 2(2), 7378. 10.26858/sportive.v2i2.9514.

Farda Kurniawan, Danang Ari Santoso, \& Wawan Setiawan. (2020). Analisis Psikologi Terhadap Kepercayaan Diri Atlet Sepakbola. JPJ (Jurnal Pendidikan Jasmani), 1(2), 47-58. https://doi.org/10.2245/jpj.v1i2.126.

Karo Karo, A. A. P., M, B. A., Sari, I. E. P., Sihombing, H., \& Sari, L. P. (2020). Effect of playing methods on the Dribble Ability of the Football Game. Kinestetik: Jurnal Ilmiah Pendidikan Jasmani, 4(2), 158-163. https://doi.org/10.33369/jk.v4i2.125 66.
Lauh, W. D., \& Fallo, I. S. (2020). Pengembangan Model Latihan Formasi Menyerang Pada Permainan Futsal. Motion: Jurnal Riset Physical Education, 11(1), 58-66.

Luh Mastia Andriani, I Gst Lanang Agung Parwata, Ni Luh Kadek Alit Arsani. (2019). Pengaruh Pelatihan 30 Second Box Drill Dan 60 Second Box Drill Terhadap Daya Ledak Otot Tungkai. Jurnal Ilmu Keolahragaan UNDIKSHA. 7(1), 28-38. 10.23887/jiku.v7i1.4097.

Mesnan, Amir Supriadi, Irwansyah Siregar. (2019). Pengembangan Log Book Pembelajaran Sepak Bola Dengan Pendekatan Taktis Jurnal Prestasi. 3(2), 68-72. DOI : 10.24114/jp.v3i6.15895.

Paranoan, A., \& Prastya, A. N. (2019). Pengembangan Model Latihan Build Up Menyerang Pada Permainan Futsal. Jurnal Ilmiah Sport Coaching and Education, 3(1), 79-92.

Rinaldi Aditya, Filli Azandi, \& M, B. A. (2020). Effect of Play Approach Against Learning Outcomes in Soccer Games. JPJ (Jurnal Pendidikan Jasmani), 1(1), 1-7. Retrieved from http://jurnal.stokbinaguna.ac.id/index .php/JPJ/article/view/104

Sugiyono. (2014). Metode Penelitian Kuantitatif, Kualitatif dan R \& D. Bandung: Alfabeta

Syahputra, W. D. (2020). Pengembangan Variasi Latihan Dribbling KOmbinasi Shooting pada Olahraga Futsal. Kesehatan dan Olahraga, 4(1), 15-26. 